\title{
IISUS HRISTOS: IDENTITATEA PERSONALĂ ÎNTRE FUNCŢIA DE MISIONAR ŞI CEA DE TRIMIS
}

Robert-Iulian Păun*

\begin{abstract}
The most significant event in the history of the telluric man was and will be forevermore, the bringing into existence the Word of God. For the Catholic Teologician Hans Urs Von Balthasar, this event radiates an absolute and pellucid light on the human intellect regarding Jesus Christ's existence and His godliness mission on the earth. The world "mission" cannot reveal the Triune knowledge, that is why, according to Balthasar, ones need to understand that Christ is the Messenger of the Father, that He is identical with His mission and through this theological riser we need to rise to the acknowledge of His Divine message of Triune revelation.
\end{abstract}

Keywords: mission, identity, revelation, testimony, transcendence

\section{Introducere}

Consonanță, acord sau simfonie sunt termenii obişnuiţi în vocabularul lui Hans Urs von Balthasar. El i-a însuşit din lectură şi din patristică (Origen, Augustin şi ceilalţi contemplativi din Evul Mediu), şi le-a dat o puternică conotaţie hristologică. Armonia care vine de la figura lui Hristos nu este rezultatul unei creaţii externe, ca şi cum primii ucenici şi prima generaţie creştină ar fi creat o dumnezeire posterioară evenimentului istoric şi intra-lumesc a lui Iisus din Nazaret. În mod contrar, aşa cum Balthasar nu oboseşte să sublinieze, această armonie străluceşte în toată frumusețea ei şi în proporționalitatea sa, chiar din interiorul esenței concrete a lui Hristos, străluceşte în toată viața Sa însemnată de primatul voii

\footnotetext{
* PhD Candidate, "1 Decembrie 1918" University of Alba Iulia, (Faculty of Orthodox Theology), Romania.
} 
Tatălui şi a împlinirii acesteia, de către Iisus, prin ascultarea filială. Simplul credincios şi exegetul poate verifica acest dat insurmontabil. Această ,verificare” duce mai întâi de toate la deducerea că, în ceea ce Î-L priveşte pe Iisus, ,în nici un punct al contemplării Sale nu se poate înțelege un defect de construcție şi de proporție a imaginii” care apare ${ }^{1}$. Dacă, într-un prim moment, am crede că am găsit în El vreo imperfecție, ar trebui mai bine să continuăm cu un discernământ mai atent, deoarece vedere noastră este cea defectă. Desigur, cu intenție apologetică, fără însă să lăsăm neevidențiat datul dogmatic fundamental, Balthasar se opreşte mult timp pentru a evidenția „dovezile" interioare ale unicităţii irepetabile ale figurii lui Iisus, care sunt garanția credibilității Sale şi baza credinței creştine în Persoana Sa. Pe scurt, subliniem acele elemente pe care le putem defini structurale, ale viziunii lui Balthasar despre armonia proprie figurii lui Iisus care se manifestă în concretul esenței Sale pământeşti.

\section{Acordul între misionar şi trimis}

Primul element, manifestat în mod luminos dinspre figura lui Hristos, este înțelegerea dintre misiune şi Cel Care este trimis. Înţelegerea acestui element, în jurul căruia Balthasar construieşte teologia sa despre misiunea hristologică, este tocmai ceea ce Hristos afirmă despre Sine în Evanghelia după Ioan: „Eu am coborât din cer nu pentru a face voia mea, ci voia Celui care m-a trimis" ( Ioan 6,38 ). Atunci când la 30 de ani, Iisus se prezintă în avanscena lumii cu maturitatea Sa de bărbat, El începe anunțul Său public cu o siguranță liniştită ştiind că are în spate, ca şi rezervă teribilă de energie, acordul dintre misiune şi Cel Care este trimis. El a făcut actual în viața Sa Cuvântul care este El Însuşi. Necesitatea urgentă pe care El o înaintează prin ,vestea Sa bună” în baza primatului lui Dumnezeu, despre Regatul Său şi al voii Sale, „va deveni credibilă oamenilor doar dacă El o trăieşte înaintea lor; nu doar acum, în momentul în

${ }^{1}$ Hans Urs von Balthasar, Gloria. Un'estetica teologica. La percezione della forma, Volumul 1, Introducere și traducere de Giuseppe Ruggieri, Milano, Editura Jaca Book, 1971, p. 468. 
care trebuie predicată, ci dintotdeauna, de când este în lume. Existența Sa este baza anunțului Său: aşa este seriozitatea Cuvântului pe care Hristos î-1 proclamă ${ }^{2}$.

Acordul, despre care este vorba, nu înseamnă doar o consonanţă de sentimente sau de voinţe dintre Tatăl şi Iisus. Termenul ,,acord” vrea să exprime mai mult decât simpla execuție ascultătoare față de voia Tatălui; asta înseamnă că toată ființa Tatălui vrea să trimită pe Fiul, care este constitutivă Fiului, deja în sânul Treimii, de a fi Trimisul Tatălui. Acordul intra-trinitar dintre Tată şi Fiu continuă în timpul întrupării, când Fiul, nici pentru o secundă, nu se opune relației Sale filiale față de Tatăl sau când El face proprie misiunea paternă realizând-o până la sacrificiul extrem de sine. Mai mult, Iisus ,a iubit misiunea $\mathrm{Sa}$ şi s-a supus ei, a asimilat-o, s-a conformat ei în orice stadiu al vieții Sale"3. Aceeaşi viaţă pământească, ca manifestare vizibilă a generării veşnice a Fiului, devine executarea plină a voii Tatălui , într-o neîntreruptă misiune". 4 Înțelegem astfel că misiunea Fiului lui Dumnezeu pe pământ este o oglindire harică a iubirii Sfintei Treimi.

\section{Perfecta corespondență între misiunea divină şi existența umană}

Punctul central de convergență sau de corespondență perfectă dintre misiunea divină a lui Iisus şi istoria sa concretă este conceptul de ,existență”. Prin „existență” Balthasar nu vrea să spună doar a trăi în timp, într-un context geografic stabilit, al unui om care a avut o poveste a sa, însemnată de un destin tragic. Aceea a lui lisus nu este o viaţă, ci este viaţa lui Dumnezeu coborâtă şi introdusă în temporalitate şi în istoricitate, din care patima şi crucea au o parte esenţială. Acum viaţa pământească a lui Hristos este şi ieşită din

2 Idem., Das Ganze im Fragment: Aspekte der Geschichtstheologie, Editura Benziger, 1963, p.293.

${ }^{3}$ Ibidem., p. 293.

${ }^{4}$ Hans Urs von Balthasar, Theologie der Geschichte. Neue Fassung, Elveția, Editura Einsiedeln, 1959, p. 25. 
timp; învierea din morți rămâne semnul intangibil, garanția luminoasă prin care existența Sa nu este doar umană, dar este mereu divino-umană. Existența lui Iisus este înțeleasă deci în cea mai profundă concretețe istorică şi în funcția Sa semantică. De aceea întruparea este văzută nu ca un ,act” punctual, dar ca un moment irepetabil care îmbrăţişează şi întregeşte arcul întreg al istoriei pământeşti a lui Hristos, de la naştere la întoarcerea la Tatăl, ca Domn glorificat. La mijlocul acestui drum se pune evenimentul crucii, eveniment pe care Iisus î-1 anticipă, aşteaptă şi culege în mod liber.

Pentru a înțelege în mod adecvat concretețea existențială a lui Iisus, ar trebui să ne gândim acum la universale concretum, un concept des folosit de către Balthasar.

Când Balthasar vorbeşte de ,acord” între misiune şi viață în Iisus, nu vrea să spună un „caz de armonie impresionantă în mod special” dintre „idee” şi existenţă, dintre „idealitate” şi realitate”; este vorba mai bine spus despre faptul că Dumnezeul cel viu ia în grija Sa toată existența Fiului Său, cu ,idealitatea” şi „,realitatea” Sa. Uitându-ne atunci la misterul global şi concret al Cuvântului Întrupat, nu doar se descoperă ,acordul dintre misiune şi existența lui Hristos”, dar se poate vedea şi ,acordul perfect dintre misiunea Sa şi existența Sa; misiunii îi aparține doctrina $\mathrm{Sa}$, dar mai ales toată datoria Sa de viață, în puterea căreia El împlineşte patima Sa în mod conform cu afirmațiile Sale. După viziunea $\mathrm{Sa}$, există o plină şi perfectă concordanţă între misiune şi existență, este „acord” între cele două realităţi şi nimeni nu poate să îi demonstreze minimul dezacord. Faptul că nimeni nu poate face acest lucru, după conştiința lui Iisus înseamnă că şi alții, cel puțin până la un anumit grad, pot să înţeleagă şi să judece acest acord perfect. Percepția lor vine cel puțin până la punctul de a putea stabili în mod negativ, absența în El al oricărui dezacord". ${ }^{5} \mathrm{Nu}$ doar pentru fapt, dar de „drept” (de iure)

${ }^{5}$ Idem, Gloria. Un'estetica teologica. La percezione della forma, Volumul 1, Introducere și traducere de Giuseppe Ruggieri, S.p.A Milano, Editura Jaca Book, 1971, pp. 450-451. 
Iisus este această armonie minunată sau ,super-acord” dintre misiunea Sa şi existenţa $\mathrm{Sa}^{6}$.

Fundamentul acestei prerogative originale este identificat încă o dată în realitatea misterului întrupării, prins în adevărul şi totalitatea Sa: uitându-ne la textele Noului Testament a sinopticilor şi a lui Ioan, trebuie să spunem că Iisus, „fiind om, este identic cu misiunea Tatălui"; fiind om, El este nespus de supraîncărcat misiunii Sale divine. $\mathrm{Nu}$ este vorba apoi despre o misiune lângă altele, asemenea profeților, dar o misiunii care conţine şi înlocuieşte pe toate celelalte (Ioan 10,1-18). În conținutul misiunii Sale divine Iisus include în mod conştiincios şi mersul spre moarte, aşteptat, dorit şi înţeles precum chintesența misiunii Sale pentru răscumpărarea lumii. Iisus nu schimbă niciodată orientarea Sa de bază, nu deviază nici un pic de la drumul Său spre cruce, nici atunci când în jurul Lui creşte aversiunea duşmanilor Săi. „Dacă linearitatea liniştită a drumului global spre propria moarte ar fi o construcție ulterioară a discipolilor, atunci aceasta ar avea o aşa zisă genialitate religioasă supraumană, care trebuie să fi depăşit mult pe cea al arhetipului. Ei ar fi trebuit să pună pe buzele lui nu doar nişte cuvinte imposibile de inventat, care atunci când au fost pronunțate au rămas neînțelese tuturor, dar ar fi trebuit să inventeze o existență care nu doar că era de acord cu acele cuvinte de atunci, dar trebuia să se demonstreze de acord şi cu moartea ulterioară şi învierea. Pentru a putea să profețească în acest fel mergând cu spatele, ucenicii ar fi trebuit să dispună de o hristologie perfectă în mod teologic, care nu este posibilă în timpul lor dacă nu este în forma unei inspirații a Duhului”. În mod contrar, chiar în puterea comportării concrete a lui Iisus, Evangheliile sinoptice arată în mod clar că „Iisus a identificat existența $\mathrm{Sa}$ cu misiunea universală primită de la Dumnezeu". 7

Toate acestea duc la concluzia că în evenimentul istoric a lui Iisus din Nazaret „misiunea este divină, execuția sa este umană; şi acordul perfect care domneşte între cele două este divino-uman”. Un

\footnotetext{
${ }^{6}$ Ibidem, p. 474.

${ }^{7}$ Ibidem, p 453.
} 
semn, într-un anumit fel extern, care duce ascultătorul pe urma acesteia, este atins de acel cuvânt pe care Iisus î-1 aruncă ca pe o provocare în arena interlocutorilor săi: „Cine dintre voi mă poate dovedi de păcat?" ( Ioan 8,46 ), adică, aşa cum interpretează autorul nostru, de dezacord, de notă falsă cu voința exigentă a Tatălui? Chiar conştiinţa de a veni de la Tatăl, de a fi trimis de către El în lume pentru a împlini „nu a mea, ci voia Ta”, îi dă lui Iisus siguranţa de a trăi mereu în unirea voii, în comuniunea de viață şi de dragoste cu Dumnezeu. În această lumină sunt studiate de către Balthasar semnele interioare care disting în mod de necontestat calitatea divină a misiunii lui Iisus, actualizată de Logos în concret şi trăită în mod concret. Aceste semne sunt citite mai ales în cele două caracteristice a lui Iisus istoric, indicate în mod clar de sinoptici; ele sunt pe de o parte autoritatea, plinătatea de puteri şi pe de altă parte dreptul de a vorbi cu autoritate proprie, de a fi Cuvânt al lui Dumnezeu şi de a împlini semne incontestabile. Cele două mişcări ale hristologiei, cu prerogativele sale care nu pot fi confundate, găsesc în ascultare amestecul lor perfect. Ascultarea lui Iisus este punctul de întâlnire a misiunii divine şi a execuţiei umane. Şi ea este divino-umană, deoarece este actul singurului Hristos, care, în unitatea Persoanei, este Cuvânt al lui Dumnezeu şi om. Ascultarea este un element structural, fundamental, în hristologia lui Von Balthasar. Ascultarea care pătrunde existența lui Hristos este semnul care nu poate fi înlocuit, care întăreşte iniţiativa Tatălui în a trimite pe Fiul cu caracteristicile lui Iisus, care duce la împlinire toată misiunea, acceptată şi făcută proprie.

Al patrulea aspect, care, pe planul existenței, întăreşte explicarea armonioasă a figurii lui Hristos şi care pune în lumină evidenţa Sa obiectivă, este identitatea dintre misiune şi doctrină, dintre doctrină şi viață. Invățătura lui Iisus este parte esențială a misiunii Sale. Aceasta, aşa cum am văzut, consistă în ,,plinătate de putere” şi în ,autoritate”, dăruită lui Hristos de la Tatăl. Această origine dă discursurilor lui 
Iisus „incomparabilitate absolută” şi „transcendență”. ${ }^{8}$ Prin transcendență Balthasar vrea să spună caracterul unic şi irepetabil al cuvântului lui Hristos: el este cuvântul lui Dumnezeu şi expresia adecvată a Sa şi totalitatea cuvântului uman, (,uman în mod universal"); mai mult El este „ultimul cuvânt al omului şi a lumii”. 9 Găsim afirmat, într-o altă formă, universalul concret a lui Iisus deoarece acest Cuvânt nu răsună în mod simplu de sus, dar s-a făcut istoricitate şi s-a pus în centrul istoriei lumii. Discursurilor lui Iisus, Balthasar le conferă o importanță capitală, deoarece ele, ,mai bine decât operele", exprimă în mod direct ceea ce El este ontologic vorbind: „Iisus Hristos este Cuvântul”. Cuvânt şi limbaj a lui Dumnezeu în cuvântul şi în limbajul omului. Om muritor ca limbaj a unui Dumnezeu nemuritor". ${ }^{10}$ În acest context este afirmată credibilitatea inerentă cuvântului însuşi. Acesta însă rămâne deasupra oricăruia „exegeză, analitică sau sistematică”; adică încercările exegezei pot ajuta sau împiedica înțelegerea Cuvântului lui Dumnezeu, dar nu o poate constitui aşa şi nu poate închide forța Sa de iradiere. Caracteristica inerentă a lui Hristos nu este doar aceea de a proteja cuvântul său (aşa cum au făcut profeții) sau de a muri pentru el; nota specifică este mai profundă: Iisus „,este acest cuvânt Însăşi”" care proclamă. Şi pentru a sublinia transcendența, adică unicitatea discursurilor lui Iisus, Balthasar afirmă că ele nu se aliniază, nici nu se cheamă unele pe altele „orizontal”, ci „trimit în mod vertical până la Logos, subzistența, care rămâne „,singurul centru divin", de la care se naşte orice cuvânt. ${ }^{11}$ Dar viaţa lui Iisus, în orizontalitatea sa istorică, oferă confirmarea originii divine a cuvântului său: „oricare cuvânt al său este garantat de toată existența

${ }^{8}$ Hans Urs von Balthasar, Verbum caro, Publicat de Johannes Verl, Editura Einsiedeln, Elveția, 1960, p. 54-55

${ }^{9}$ Ibidem, p. 54.

10 Hans Urs von Balthasar, Das Ganze im Fragment: Aspekte der Geschichtstheologie, Editura Benziger, 1963, p.264

${ }^{11}$ Ibidem., p. 265. 
Sa”. ${ }^{12}$ Această ,acoperire” constituie soliditatea discursurilor lui Iisus. De aceea se poate spune că „cuvântul său pronunțat este existență exprimată” şi ,existența Sa este, în globalitatea sa, cuvânt”, în corelație perfectă „între ceea ce este exprimat şi exprimare". ${ }^{13}$

Insistând asupra aspectului primar al cuvântului, ar putea să se nască idea că autorul înjoseşte operele lui Hristos şi goleşte sensul miracolului. Această suspiciune pare să vină din interpretarea pe care el o dă pasajului de la Ioan 10, 36-38, „operele sunt mai bine spus ajutor pentru cei care nu pot înțelege”, ,sunt un surogat pentru cei grei de ureche". ${ }^{14}$ Dar şi dacă Balthasar, cum vom vedea, dă o interpretare specială miracolelor, el nu vrea să separe discursurile lui Iisus de acțiunile prodigioase; vrea să afirme direct inseparabilitatea cuvântului lui Iisus de existența Sa, mai mult identitatea dintre cele două. Doar în contextul vieții lui Hristos cuvântul Său achiziționează adevărul plin şi funcția sa revelatoare, trinitară. Semnele care provoacă această identitate sunt citite în ascultarea faţă de Tatăl, în blândețea şi în dorința de a-L servi pe El; în cele din urmă în concordanța plină dintre profeție şi împlinire.

Această accentuată subliniere a corespondenței perfecte în Iisus între misiune - viață - doctrină decurge şi de la grija de a nu cădea în reducerile făcute de „metoda criticei istorice”. Tonul, în acest sens, este polemic des şi poate părea apologetic. Dar miza este mare: este vorba nu doar de înțelegerea harismei (kerigma), pe care a avu-o Biserica primitivă, dar şi de conţinutului ei. După Balthasar, critica istorică a făcut un „masacru filologic” şi a căzut într-o „enigmă plină de contraziceri”, pentru că a adăugat o separare ,alternativă” între Iisus al istorie şi Iisus al credinței, între un Iisus profet după Vechiul Testament (Sinoptici) şi un Iisus îndumnezeit (Paul şi Ioan), făcând şi o separare între cel Răstignit şi cel Înviat.

\footnotetext{
${ }^{12}$ Hans Urs von Balthasar, Verbum caro, Publicat de Johannes Verl, Editura Einsiedeln, Elveția, 1960, p. 32.

${ }^{13}$ Ibidem., p. 33.

14 Hans Urs von Balthasar, Das Ganze im Fragment: Aspekte der Geschichtstheologie, Editura Benziger, 1963, p. 264.
} 


\section{Unicitatea şi irepetabilitatea misiunii lui Iisus Hristos}

La întrebarea: Cine este Isus Hristos?, Balthasar, deja în primul volum din Gloria, ne-a dat un răspuns decisiv: „Fiind om (El) este identic cu misiunea Tatălui".

„El este cheia pentru a clarifica cunoaşterea nu doar despre creație, dar şi despre Dumnezeu. El este cheia nu doar prin medierea învățăturii Sale, prin adevărul protejat de El, fie că este acesta universal sau singular, dar mai ales şi în mod esențial prin existența $\mathrm{Sa}$. Nu se poate separa cuvântul Său de existența Sa; având adevărul doar în contextul vieții Lui, al angajamentului Său pentru adevăr şi pentru dragostea față de Tatăl până la moartea pe cruce”; această „identitate dintre cuvânt şi existență” Iisus o trăieşte în toată viața Sa ca serviciu şi ascultare faţă de Tatăl. ${ }^{15}$

Plecând de la acest dat originar al hristologiei Noului Testament, se poate stabili confrontul calitativ dintre Iisus, profeții Vechiului Testament, miturile greceşti şi întemeietorii de religii. $\mathrm{Cu}$ alţi termeni, este vorba despre a studia mai profund unicitatea figurii lui Hristos şi de a o motiva, deoarece, în puterea calităţii sale interioare, el nu este un unic relativ la fel ca celelalte mari figuri sau instituții religioase ale istoriei, dar este unicul absolut, separat în mod calitativ de ele şi mai mare decât ele. Acest punct al hristologiei ni se pare foarte important şi urgent, ținând cont că, şi înăuntrul teologiei catolice, în numele unui dialog inter-religios de tip sincretist, există deja poziții care nu doar că pun creştinismul pe acelaşi nivel cu celelalte religii (semitism, islamism, budism şi hinduism), dar care văd un viitor al creştinismului „fără Hristos”; la sfârşit - cum susţine Hans Küng - ar rămâne doar Dumnezeul Inexprimabil, în care s-ar regăsi toate religiile lumii.

Sensul pe care Balthasar îl are despre misterul lui Hristos este diametral opus față de cel al compatriotului său Küng. Focalizând

\footnotetext{
${ }^{15}$ Idem, Theologie der Geschichte. Neue Fassung, Elveția, Editura Einsiedeln, 1959, p. 18.
} 
propria sa reflecţie despre conceptul misiunii, Balthasar găseşte şi dezvoltă, pe două nivele, unicitatea absolută a lui Iisus Hristos, ca figură centrală a revelaţiei lui Dumnezeu şi ca mediator a mântuirii universale. Primul nivel, deja formulat în eseurile_precedente hristologice ca cele din Verbum Caro, este dezvoltat mai ales în Estetica teologica; al doilea nivel este obiect de dezvoltare amplă şi articulată, fie literară fie teologică, în domeniul Teodramaticii. Primul nivel se mişcă pe planul manifestării divine; al doilea nivel aparține acțiunii soteriologice, deci dramaticii teologice. Vedem, chiar dacă în formă sintetică, răspunsul lui Balthasar asupra raportului, în Iisus, între Persoana Sa şi Misiunea Sa. Unele dintre aceste aspecte le-am văzut deja; este vorba acum de a ne gândi din nou la ele într-o relaţie mai strânsă punctului central şi decisiv al discursului: Iisus Hristos ca identitate dintre persoană şi misiune divină, deci coincidență perfectă a voii Sale libere cu voia mântuitoare a lui Dumnezeu Tatăl.

\section{Rolul Sfântului Duh în misiunea istorică a lui Iisus}

Un aspect, care face perfectă imaginea armonioasă a lui Hristos, ca figură unică şi irepetabilă de revelație şi deci de mântuire, este văzută în mod amplu în acțiunea Sfântului Duh în persoana lui Hristos şi în misiunea sa de dezvăluitor şi de răscumpărător. Metodei istorico-critice îi este reproşat în mod aspru de a transcura aproape de tot aspectul pneumatologic ( inspirație) a revelației biblice, de aceea Sfânta Scriptură este folosită de exegeza ca un oarecare text literar; făcând un „masacru filologic” a textelor, aceeaşi metodă istorico-critică, după Balthasar se foloseşte de Sfânta Scriptură de parcă ea ar fi o ,carieră de piatră”, ale cărei elementele sunt ecranate, alese şi aruncate din nou în baza unui principiu rațional, aproape fără să țină cont de faptul că Biblia însăşi a fost scrisă „,cu inspirația Sfântului Duh". Metoda istorico-critică, acceptând ca dat obiectiv contrastul dintre aşa zisul Iisus istoric şi Iisus al credinței, consideră credința ca o ,parte” pusă în fața lui Iisus cel istoric. Însă, acțiunea Sfântului Duh, cu dinamica sa, este mereu subliniată de Balthasar ca 
puterea care unifică, care animă toată figura lui Hristos, îi dă plasticitate şi o face de neconfundat cu oricare altă figură religioasă a umanității. Este cu adevărat Sfântul Duh cel care pune în lumină fundamentul cel mai ascuns al evidenței obiective a lui Iisus, care lasă să se vadă chiar în istoricitatea sa concretă ,,corespondența trinitară" dintre Tatăl, Fiul şi Sfântul Duh a dragostei însăşi. Fără Sfântul Duh, care este „dezvăluitorul” (Ausleger) lui Iisus, deci Cel care Î-L explică, Î-L expune şi Î-L arată credinciosului, şi ,,imaginea care duhul nostru poate să şi-o o facă de Iisus, rămâne ştearsă şi unilaterală, deoarece nu este capabil de a îmbrăţişa acele tensiuni prin care Iisus dezvăluie comportamentul interior a lui Dumnezeu în universalitatea sa”. Este propriu Duhului Sfânt, ca „Duh al adevărului”, să conducă credincioşii la ,adevărul întreg” ( Ioan 16,19 ), adică înțelegerii adevărului divin care este Iisus Hristos Însăşi ( Ioan 14,6 ).

Dar Sfântul Duh încă de la întruparea Cuvântului a exercitat toată dinamica sa în evenimentul hristologic: „Rolul Duhului consistă nu doar în a găsi în omul Iisus instrumentul corect pentru ascultarea istorică a Fiului, dar în mod concret pentru a pune pe Fiul, cu umbrirea Fecioarei în stadiul umanități”. Aşa afirmă clar formulele Crezului. $\mathrm{Cu}$ alte cuvinte, este Sfântul Duh cel care „produce Cuvântul întrupat”, care „leagă ființa necreată şi fiinţa creată”: prin ,apriorica ascultare” a lui Hristos, care nu „ia” de la sine umanitatea Sa, dar se ,abandonează” în mod activ la mişcarea Sfântului Duh care Î-L face om; în a se abandona Duhului, Fiul, făcut om, devine şi un rezultat al Duhului care $\hat{1}-\mathrm{L}$ face om din Fecioara Maria, chiar dacă în relaţiile intra-trinitare Duhul este rezultatul veşnic a suflării Tatălui. Aceasta este „,inversiunea trinitară”, despre care vorbeşte în mod original autorul nostru: această ,inversiune” este pasajul de la Treimea imanentă la Treimea economică în care Sfântul Duh are rolul de mediator activ pentru a asigura Fiului „,ascultarea Sa apriorică” voii Tatălui. Sfântul Duh continuă funcţiunea $\mathrm{Sa}$ de mediator în viața şi în misiunea lui Iisus, deoarece auto-abandonului său față de Tatăl sau ,,ascultare apriorică”, care nu este ,pasivitate pură”, ci angajament suprem, prezintă voia Tatălui în 
forma unei „reguli” necondiționate, ,regulă” care în timpul patimii se face chiar inexorabilă. Textele lui Ioan mărturisesc despre „trimisul” Tatălui, după care datoria primară a Fiului este aceea de a nu face propria Sa voie ( Ioan 5,30 ), dar de a oferi viața Sa pentru mântuirea lumii, deoarece a avut El însuşi ,puterea de a o oferi şi puterea de a o relua din nou" ( Ioan 10,18 ). În timpul patimii, când poate a dispărut chipul de dragoste al Tatălui, Sfântul Duh mărturiseşte lui Iisus decizia trinitară, a Tatălui şi a Fiului, despre mântuire. Acestei „reguli”, reprezentată de mişcarea Sfântului Duh, Cuvântul întrupat pare a-i răspunde: „Asta este ceea ce voi ați vrut de la eternitate, tot atât cât noi am decis din veşnicie" 16 .

De la toate aceste elemente, se poate afirma că revelația divină, făcută în timp de Cuvântul devenit om, nu se bazează deloc pe o auto-dumnezeire a lui Iisus, lucru care ar suna ca o nebunie pură sau ca un hibris de neiertat; ea nu începe nici de la o dumnezeire posterioară din partea ucenicilor săi: revelația însăşi a lui Dumnezeu, cu greutatea sa eshatologică, vine însă de la conştientizarea că Iisus are conştiința că El însuşi este Fiul veşnic a lui Dumnezeu, trimis în lume pentru a manifesta în chipul Său uman chipul invizibil al Tatălui şi pentru a împlini în persoana Sa de Trimis aceeaşi acțiune de mântuire universală, voită de Tatăl şi de Fiul în Sfântul Duh. Toate acestea sunt în urma evenimentului întrupării a Cuvântului, în puterea căreia Iisus Hristos este şi rămâne „Centrul în plinătatea timpului ". ${ }^{17}$

Chiar în această ființă, El, Iisus din Nazaret, aceeaşi misiune a Tatălui, actualizată în ascultarea filială şi dusă până la suprema jertfă de sine pe cruce, atinge punctul decisiv şi omnicomprensiv al unicității lui Hristos, ca figură centrală a revelației trinitare. Aşa cum am putut vedea, toată Estetica teologică a lui Balthasar se învârte în jurul ideii ,acordului perfect” , în Iisus, între misiunea divină şi existența Sa umană. Teodramatica reia aceeaşi idee, aprofundând şi

\footnotetext{
${ }^{16}$ Hans Urs von Balthasar, Teodrammatica. Le Persone del Dramma: L'uomo in Cristo, Volumul 3, Editura Jaca Book, Traducere de Guido Sommavilla, Milano, 1983, p. 189.

${ }^{17}$ Idem, Theologie der Geschichte. Neue Fassung..., p. 18.
} 
demonstrând, că Iisus Hristos însăşi este „identitatea personală dintre Misiune şi Trimis”, Persoana Sa nefiind altceva decât „rolul” pe care El î-1 interpretează şi î-l face pe scena lumii, în ascultarea față de Tatăl, pentru mântuirea noastră. Dar înainte de a intra în categoriile dramatice, este necesar să ne oprim din nou asupra Esteticei teologice, pentru a surprinde structura şi specificitatea hristologică pe planul revelației (evidența obiectivă), şi pe planul percepției credinței (evidența subiectivă). Cum vom vedea, această structură, după terminologia lui Balthasar, este constituită din „doctrina percepției” și din „doctrina extazului”.

\section{Misiunea ca măsură a existenței şi conştiinței lui Hristos}

„Eu am coborât din cer pentru a face, nu voia mea, ci voia Celui care m-a trimis”, Autorul a găsit în mod clar în misiune „,cheia la toată existența lui Iisus" (Ioan 3,38), cheia interpretativă a „existenței Sale primite", structurată în două poluri: polul negativitătii (a nu face, a nu împlini, a nu căuta propria ta voie) şi polul pozitivității (împlinirea voii Tatălui) ${ }^{18}$. Perfecțiunea Fiului constă în ascultare, în a parcurge timpurile; respingerea de a anticipa timpurile este acelaşi lucru cu acceptarea lor, cu ,un da" spus de Sfântul Duh, care comunică de fiecare dată voia Tatălui într-o anumită clipă.

În ceea ce priveşte raportul lui Iisus cu vechiul Pact, "pentru ca să fie îndeplinită Scriptura", nu se poate vorbi de o dependență extrinsecă a misiunii Sale de drumurile misionare deschise sau care au fost deja parcurse în Vechiul Testament, ,pentru că El conține în întregime şi în libertatea care trebuie încă definită, totalitatea de ceea ce 1-L precede în mod fragmentar. Ascultarea Sa este mereu repetată, nu este întoarsă spre Moise şi spre ucenici, ci doar spre misiunea Sa, adică spre Tatăl, care este Cel care trimite. Acum apare la lumină paradoxul fundamental al autoconştiinței şi a conştiinței misiunii Sale. Acest paradox constă în faptul că misiunea nu este setată la „Eul” lui Hristos de către ceva extern lui, de o lege străină sau

${ }^{18}$ Ibidem, p. 22. 
distinctă de El: Eul său este precis identic cu misiunea. Asta, şi nu alta, este „legea” Sa, motivul, scopul vieții Sale. Dintotdeauna, Iisus nu are altă conştiință în afară de cea a misiunii. Asta înseamnă, repetăm, că El nu a fost într-un prim moment un „Eu privat şi autonom", care, într-un alt moment, s-a deschis sau s-a trezit brusc către percepția unei misiuni superioare, divină, de valoare universală. Invers, Iisus este „cel care a avut mereu datoria, mai bine spus care este datoria, de a realiza această universalitate la care orice lucru din El, memoria, intelectul şi libera voie, este conformată". Deci între Iisus şi misiunea supranaturală există identitate şi nu doar simplă adecvare sau conformație în timp, „deoarece Iisus este acest om determinat pentru misiune" 19 .

Cuvântul ,identitate”, adică egalitatea în Iisus Hristos dintre cele două concepte (persoana şi misiunea), rămâne un cuvânt puternic, nestăpânit, a hristologiei lui Balthasar. Această „identitate” înseamnă că misiunea lui Iisus nu este ceva adăugat persoanei Sale, dar este egală cu ea; deci natura intimă a lui Iisus, Fiul, este faptul de a fi mereu şi din totdeauna cel Trimis.

Având în vedere că misiunea Sa este divină sau supranaturală, acelaşi subiect spiritual (Hristos) care o duce şi o pune în aplicare în lume este de natură divină. Iisus, cum am mai subliniat, este tocmai cel trimis de Tatăl deoarece este Cuvântul făcut carne, conceput prin lucrarea Sfầntului Duh.

Balthasar a demonstrat cu putere că între misiunea lui Iisus şi existența Sa există o armonie perfectă, mai mult că omul Iisus este identic cu misiunea Tatălui, din acest motiv misiunea însăşi este divină şi execuția în Hristos este umană: urmează faptul că între cele două (misiune şi executare), domneşte o proporție plină, un acord divino-uman. Începând de la această identitate dintre misiune şi persoană în Hristos, Balthasar poate afirma de asemenea coincidența în El dintre conştiinţa de sine (autoconştiinţa) şi conştiinţa misiunii,

\footnotetext{
${ }^{19}$ Hans Urs von Balthasar, Teodrammatica. Le Persone del Dramma: L'uomo in Cristo, Volumul 3, Traducere de Guido Sommavilla, Milano, Editura Jaca Book, 1983, p. 158.
} 
aceleia dintre ştiință şi conştiință misionară: „Cunoaşterea lui Iisus de Sine coincide cu cunoaşterea Sa despre misiunea primită"; acum „misiunea despre care Iisus este conştient este misiunea singurului Fiu", motiv pentru care este o conştiinţă de misiune trinitară, universală . În toată existența Sa „Iisus trăieşte conştiinţa Sa umană ca misiune în mod perfect”, deoarece „El este cel care a spus dintotdeauna "da" la această misiune: ,de asta eu am venit" (Ioan 10, 10). Într-un cuvânt, se poate spune că Iisus Hristos „,se dăruieşte total misiunii Sale, este acelaşi lucru cu ea, este Cel trimis" ${ }^{" 20}$. Cu alte cuvinte, în timp ce noi primim prin credință misiunea noastră specifică, „Iisus are şi este dintotdeauna misiunea Sa şi este, în misiunea Sa, absolutul dependent şi credincios Tatălui Care trimite". ${ }^{21}$ Deci conştiinţa pe care o are despre misiunea Sa nu lasă doar să se conştientizeze că a primit o datorie divină specială (aşa cum este cazul ucenicilor sau a întemeietorilor de religii), dar în datul original, El este identic cu această datorie, în datul cel mai intim al Eului Său. De aceea spunând acelaşi lucru, Iisus nu are doar misiunea divină, dar este acelaşi lucru pe care î-1 predică şi î-1 trăieşte, ducând la împlinire planul de mântuire a lui Dumnezeu Trinitar: să ia păcatul lumii, să reconcilieze lumea cu Dumnezeu. Aici stă, pentru Balthasar, sursa adevăratului concept teologic a persoanei în hristologie: "Pentru că Iisus împreună cu misiunea Sa în care este prezentă filiația Sa divină, este El persoana primă ${ }^{, 22}$.

Fiind cel trimis, Iisus este adevărul lui Dumnezeu pentru mântuirea lumii, deoarece El este ,cel care dezvăluie voia, sentimentul şi opera Tatălui”; nu doar că Iisus mărturiseşte adevărul lui Dumnezeu, dar El este acest adevăr: numai Iisus poate în acelaşi timp să fie adevărul şi să î-1 mărturisească, pentru că este singurul care a venit de la Tatăl, trimis de El şi cel care î-L „explică”.

Am spus deja că misiunea de care Iisus este conştient este cea a

\footnotetext{
${ }^{20}$ Ibidem, p.145, 156.

${ }^{21}$ Ibidem., p. 162.

${ }^{22}$ Hans Urs von Balthasar, L'autocoscienza di Gesu, în „Revista Internațională de Teologie și Cultură - Communio" nr. 42-43, Editura Jaca Book, Milano, 1978-1979, p. 84.
} 
singurului Fiu veşnic a lui Dumnezeu, nedespărțit de Tatăl. Şi Tatăl, în misiunea lui Iisus, este mereu prezent fie în privire, putem spune „retrospectiv”, în raport cu cel care trimite, fie în prospectiva ,spre în față”, spre executarea acestei misiuni. Chiar dacă lucrează cu libertatea Sa de Fiu, cu tot angajamentul său de om responsabil, Iisus priveşte mereu la Tatăl care L-a trimis şi care vrea să împlinească doar voia Sa până când va suporta cele trei mari tentații, până când va bea paharul amar al patimii şi a morții. Misiunea lui Iisus, Fiul nu se poate izola în nici o clipă de către cel care trimite, de Tatăl.

La baza acestei înțelegeri hristologice există mereu trimiterea explicită sau cel puțin implicită la gândirea tomistă: presupusă creația lumii şi a omului, procesul intra-divin şi misiunea extra-divină ,sunt pentru Persoanele divine acelaşi lucru, chiar şi acolo unde Fiul şi Duhul intră în vizibilitatea creației"; în relație cu misiunea Fiului şi a Duhului în lume (una cât şi cealaltă sunt supuse misiunii). Deci misiunea lui Iisus Hristos în lume este o modalitate a naşterii sale veşnice a Fiului de la Dumnezeu Tatăl. În al doilea rând, conştiinţa pe care omul Iisus o are despre misiunea Sa în timp ca misiune veşnică a Fiului lui Dumnezeu implică o trimitere fie lucrării Sale fie ascultării Sale: ,omul Iisus ştie că atunci când El face în libertate este lucrarea Fiului lui Dumnezeu. El nu execută ceea ce a decis să facă altcineva; El este, şi în timp, tot cel care se oferă Tatălui pentru a împlini opera răscumpărării lumii; în momentele în care greutăţile imense L-au zdrobit uman, această ofertă se manifestează din nou în scena Grădinii Măslinilor). În nici un fel Iisus ca om se ascultă pe sine ca fiind Dumnezeu, nu ascultă nici de Treime, dar fiind Fiu ascultă în Sfântul Duh de Tatăl”. Pentru că Hristos, „Trimisul”, este mereu „Inspirat”, El „învață misiunea $\mathrm{Sa}$ absolut nu ca o constrângere, dar invers ca şi ceea cu care El se identifică în mod liber cu toată inima, cu tot sufletul şi cu toate puterile",23.

${ }^{23}$ Hans Urs von Balthasar, Teodrammatica. Le Persone del Dramma: L'uomo in Cristo, Volumul 3, Traducere de Guido Sommavilla, Milano, Editura Jaca Book, 1983, p. 213. 


\section{Transcendența lui Hristos față de profeți şi de toți întemeietorii de religii}

În primul volum din Estetica teologică: La percezione della forma, care se ocupă de ,calitatea” originală a figurii lui Hristos, sunt enumerate patru directoare, care arată tot atâtea diferențe, pentru a arăta unicitatea absolută a lui Hristos față de toți ceilalți întemeietori de religii. În acest prim nivel ne mişcăm mai ales în brazda teologiei fundamentale, care este totuşi nedespărțită de teologia dogmatică. Primul element al specificității lui Hristos, izolat şi ireductibil, față de oricare altă figură a istoriei religiilor, este astfel formulată: „În timp ce ceilalți întemeietori sunt nişte euri înțelepte care trimit către un „drum” găsit de ei, dezvăluit lor, Iisus, de la început, se prezintă pe sine ca pe un drum. Drumul pe care î-1 prezintă ceilalți întemeietori poate fi o doctrină despre cum se moare lumii pentru a renaşte în Dumnezeu, dar poate fi şi mitul lui Dumnezeu care moare şi învie, coboară şi urcă. În nici un mod, fundamentul istoric se poate identifica cu mitul. Extaziați şi în mod tangibil, vor fi mai târziu ucenici săi care $\hat{1}-\mathrm{L}$ vor considera ca o întrupare a lui Dumnezeu cel anunțat. Iisus însă găseşte în Sine forma doctrinală şi forma vieții şi nu doar până la moarte, ca angajament şi demonstrație a dragostei ( Ioan 15,13 ) ci până la înviere. Sub acest aspect se mai poate spune că figura lui Hristos este ,identitatea de mit şi de realitate istorică”. ${ }^{24}$

A doua direcție a diferenței priveşte vocaţia întemeietorilor de religii şi începutul misiunii lui Iisus. Dintre primii, pentru a face credibilă misiunea lor, este povestit momentul unei conversiuni decisive a lor, deci a iluminării sau a răpirii: „Ei erau telurici şi au fost iniţiați la cer” şi acum trebuie să iniţieze pe alţii la aceeaşi revelație. În această experienţă religioasă intră şi profeții Vechiului Testament, care, în urma unei chemări, văd misiunea lor care trebuie să fie împlinită în lume. Şi profetul este un simplu om, care, pe scurt

${ }^{24}$ Idem., Gloria. Un'estetica teologica. La percezione della forma, Volumul 1, Introducere și traducere de Giuseppe Ruggieri, S.p.A Milano, Editura Jaca Book, 1971, p. 484. 
sau pe lung timp, în urma unei alegeri singulare, este responsabil de o misiune divină. Totuşi, şi când trebuie să pună la dispoziția misiunii primite toată întreaga existență a sa (ca în cazul lui Osea şi a lui Ieremia), în profetul biblic nu se poate vorbi despre o identificare a sa cu misiunea. Aceasta este dată în timp (profet se devine) şi este supraîncărcată de greutatea cuvântului unui Altul, a lui Dumnezeu, care vorbeşte „prin” sau „cu ajutorul” profetului. Acesta într-adevăr nu se identifică niciodată cu, Cuvântul lui Dumnezeu, care are în Dumnezeu, şi nu în persoana profetului, sursa primară al anunţului şi puterea execuției. Faptul că Iisus nu poate fi aliniat în rândul profeților veterotestamentari apare clar şi de la opoziţia dintre Iisus şi Ioan Botezătorul, ultimul dintre marii profeți. În predica sa şi în acțiunea sa Botezătorul este întins tot spre un „altul”, care „va veni” după el, care este „mai puternic” decât el deoarece este ,înaintea” lui. Punând în paralel invitaţia de convertire a Botezătorului şi a lui Iisus: „Pocăiți-vă pentru că regatul cerurilor este aproape” ( Matei 3,2 ), apare definită diferența calitativă a celor două chemări: „Botezătorul invocă pe Cel care vine după el; Iisus nu se referă la nimeni după El; în spatele Lui nu mai vine nimeni, El este identic cu conținutul chemării Sale (er ist mit dem Inhalt seines Rufes identisch)"25.

Cum am văzut deja, elementul determinant este faptul că Iisus, fiind om ,este identic cu misiunea Tatălui”. De asta este imposibil de găsit în Hristos un moment de vocaţie sau de convertire la cauza lui Dumnezeu Tatăl; nici botezul Său, consacrat de pogorârea Duhului peste El, poate fi adoptat ca şi moment de început a hristologiei. Întradevăr, ,identificarea presupusă în predica lui Iisus, între doctrina Sa şi toată existența Sa", manifestă imposibilitatea unei experiențe de conversiune în viața lui Hristos. Conştiința lui Iisus de a fi coborât din cer, de a veni de sus ( Ioan 3,13 ), î-L pune în opoziţie cu toți ceilalți care sunt „,de jos”. La fel de radicală este diferența dintre moartea lui Iisus şi cea a muritorilor sau a dumnezeilor care mor şi învie: moartea acestora (Tammuz, Adonis, Attis sau Baldur) este sub semnul ,destinului”, în care forța care îi învie este mai puternică

${ }^{25}$ Ibidem, p.453. 
decât destinul. Evanghelia lui lisus anunţă însă „mântuirea în moarte”, unde extrema impotență „devine dezvoltarea supremă de putere, unde cel mai mare dezastru devine mântuire: în crucea lui Hristos drama ruinei umane se transformă, în totalitatea sa, în exprimarea dragostei veşnice. Iisus a înviat în întunericul iadului.

A treia diferență atinge raportul dintre miturile aducătorului de mântuire şi Iisus Hristos. Primii sunt nişte fenomene naturale şi, în cel mai bun caz, protologici şi eshatologici. Evenimentul lui Hristos se înrădăcinează însă în istorie şi vrea să fie înțeles în sens istoric astfel precum tot chipul Său revelator şi de mântuitor este nedespărțită de revelația istorică a Vechiului Testament. Pentru faptul că „,centrul revelației biblice rămâne istoric”, din acelaşi motiv el se distinge de miturile şi de misticele cosmice. Mituri religioase şi mistice cosmice aveau doar posibilitatea de a nega ființa lumii ca atare, în favoarea ființei divine, sau de a resuscita , prin dezordinea şi uitarea umană, legea originală care pătrunde în mod divin ființa lumii. După această concepție naturalistică sau cosmică, se credea că la baza acestei legi a lumii locuieşte mântuirea, că legea lumii însăşi ar fi în mod esențial mântuirea. Încă o dată, ceea ce este decisiv în ceea ce priveşte creştinismul este faptul că acțiunea de mântuire transformatoare a lui Dumnezeu este în acelaşi timp acțiunea unui om care se sacrifică din dragostea pentru noi toți. Doar această dragoste care lucrează şi suferă şi care cere să fie urmărită, imitată, prin dragostea pentru aproapele nu lucrează în puterea unei legi cosmice, ci mulțumită libertății dragostei sale care transcende aceleaşi legi ale lumii (H. De Lubac). Creştinismul nu neagă deloc ființa lumii, ci modul său de a fi departe de Dumnezeu, statul său de decadență.

A patra directoare, pentru a sublinia unicitatea absolută a figurii lui Hristos pe planul religiilor lumii, priveşte raportul cu imaginea lui Dumnezeu, comună cu religiile şi specifică revelației creştine, adică Trinitatea. Ceilalți întemeietori de religii rămân prizonieri dialecticei dintre Dumnezeu şi lume precum între Unu şi diferitul (multiplul): există un drum care consistă în a rămâne între Unu şi multiplu (Mahomed), cea care suprimă multiplul în favoarea Unului (sunt 
toate formele de mistică extra-creştină, inclusiv Sufismul), sau de a integra Unul în multiplu (politeism şi panteism). Trinitatea care se dezvăluie în Iisus Hristos luminează însă raportul dintre Dumnezeu şi om într-un mod cu totul nou şi foarte original; sunt nesecate posibilităţile care se deschid de la această revelaţie, care elimină aspectele nesatisfăcătoare a toate celorlalte căi de revelație: „Fiul, Cuvântul Tatălui ne permite să aruncăm o privire în profunzimile divine. Apare atunci ca Dumnezeu şi în acelaşi timp Unicul (în natura Sa spirituală), şi Dragostea veşnică, fără umbra acelui egoism care apasă pe religii precum fatum şi necessitas. Şi de aici se vede, mai mult, ca o lume, chiar dacă diferită şi multiplă, poate fi justificată fără ca el să apară ca o necesitate pentru unitatea lui Dumnezeu", pentru ca Dumnezeu să ajungă la El însuşi prin lume. În special, mulțumită existenței diferenței Persoanelor divine în Dumnezeu (Tată, Fiu şi Sfântul Duh) celălalt al creaturii este justificat în esența sa prin celălalt, în sânul identităţii lui Dumnezeu însuşi: Omul-Dumnezeu este integrat în revelaţia Tată-Fiu; şi creaţia, care are început de la libertatea lui Dumnezeu, nu poate pretinde nici o necesitate pentru existența sa, doar aceasta este justificată în existența sa deoarece este exprimarea dragostei trinitare: dar al Tatălui pentru Fiul, întoarcerea Fiului la Tatăl, transfigurarea dragostei Tatălui şi a Fiului mulțumită Sfântului Duh. În acest sens şi doar în aceasta, precizează Balthasar împreună cu toată filozofia creştină, se poate spune că lumea „eset diffusio bonitatis divinae”; aceeaşi doctrină trinitară apare ca unica şi posibila ,teodicee a lumii”" deoarece întruparea Cuvântului însuşi duce la împlinirea creaţiei care „deja în mod ontic era bazată în mod dublu în Trinitate (după esență şi după existență)".

\section{Concluzii}

În tratarea acestui subiect de identitate între funcția de misionar şi cea de trimis în persoana lui Iisus Hristos, accentul cade pe caracterul unic şi revelaţional al misiunii Mântuitorului în lume. Putem înțelege misiunea Sa ca o reflecție a ceea ce este Dumnezeu în 
cadrul relaţiilor inter-personale, deci ca o oglindire, ca o deşertare a Treimii imanente. Misiunea îşi pierde înţelesul mărginit al umanului slujind la îndepărtarea vălului care acoperă întreaga activitate a Domnului Iisus. Misiunea lui Iisus are origine divină, şi de aceea autorul nostru, Hans Urs von Balthasar, încearcă să înlăture vălul care ar putea obscura această evidență. Analizând efectele acestei misiuni uriaşe în persoana divino-umană a Mântuitorului, teologul elvețian riscă să înțeleagă care sunt repercursiunile ei asupra umanului şi mai mult asupra conştiinței umane. Această tendință de a explora tărâmuri inaccesibile este o tendință prezentă la teologii romano-catolici, şi se datorează, cred ( în urma experienței de a trăi printre ei aproximativ zece ani ), dorinței de a-l trăi pe Hristos de la o anumită distanţă printr-un fel de empatie duhovnicească.

\section{Bibliografie:}

1. Balthasar, Hans Urs von, Das Ganze im Fragment: Aspekte der Geschichtstheologie, Editura Benziger, 1963.

2. Idem, Gloria. Un'estetica teologica. La percezione della forma, Volumul 1, Introducere şi traducere de Giuseppe Ruggieri, S.p.A Milano, Editura Jaca Book, 1971.

3. Idem, L'autocoscienza di Gesu, în Revista Internațională de Teologie şi Cultură, Communio nr. 42-43, Editura Jaca Book, Milano, 1978-1979.

4. Idem, Teodrammatica. Le Persone del Dramma: L'uomo in Cristo, Volumul 3, Editura Jaca Book, Traducere de Guido Sommavilla, Milano, 1983.

5. Idem, Teodrammatica. Introduzizone al Dramma, Volumul 1, Editura Jaca Book, Traducere de Guido Sommavilla, Milano, 1973.

6. Idem, Teologica. Verita di Dio, Volumul 2, Editura Jaca Book, Traducere de Guido Sommavilla, Milano, 1985. 
7. Idem, Theologie der Geschichte. Neue Fassung, Elveția, Editura Einsiedeln, 1959.

8. Idem, Verbum caro, Publicat de Johannes Verl, Editura Einsiedeln, Elveția, 1960.

9. Haecker, Theodor, Was ist der Mensch?, Leipzig, Editura Hegner, 1934. 